\title{
Effects of dapagliflozin in experimental sepsis model in rats
}

\author{
Zehra Betül Kıngır, M.Sc., ${ }^{1} \odot$ Zarife Nigar Özdemir Kumral, Ph.D., ${ }^{2} \odot$ Muhammet Emin Çam, Ph.D., $^{3}$ \\ Özlem Tuğçe Çilingir, Ph.D., 4 @ Turgut Şekerler, M.Sc., ${ }^{5}$ ๑ Feriha Ercan, Ph.D., ${ }^{4}$ \\ ๑ Özlem Bingöl Özakpınar, Ph.D., ${ }^{5}$ @ Derya Özsavcı, Ph.D., ${ }^{5}$ @ Mesut Sancar, Ph.D., ${ }^{1}$ @ Betül Okuyan, Ph.D. ${ }^{1}$
}

\author{
${ }^{1}$ Department of Clinical Pharmacy, Marmara University Faculty of Pharmacy, İstanbul-Turkey \\ ${ }^{2}$ Department of Physiology, Marmara University Faculty of Medicine, İstanbul-Turkey \\ ${ }^{3}$ Department of Pharmacology, Marmara University Faculty of Pharmacy, İstanbul-Turkey \\ ${ }^{4}$ Department of Histology and Embryology, Marmara University Faculty of Medicine, İstanbul-Turkey \\ ${ }^{5}$ Department of Biochemistry, Marmara University Faculty of Pharmacy, İstanbul-Turkey
}

\begin{abstract}
BACKGROUND: The aim of this study was to evaluate the possible protective effects of dapagliflozin in an experimental sepsis model in rats.

METHODS: Saline ( $\mathrm{l} \mathrm{mL} / \mathrm{kg}$, p.o.) or dapagliflozin ( $10 \mathrm{mg} / \mathrm{kg}$, p.o.) was administered to Sprague-Dawley rats for 5 days prior to the surgical procedures. Under anesthesia, sepsis was induced by cecal ligation puncture, while sham control groups underwent laparotomy only. Blood urea nitrogen, creatinine, and glucose levels were measured in serum samples and the levels of malondialdehyde (MDA), glutathione (GSH), myeloperoxidase (MPO), tumor necrosis factor alpha, interleukin I beta, caspase 8, and caspase 9 were determined in tissue samples (kidney, liver, and lung). Histological evaluation was also performed.
\end{abstract}

RESULTS: The administration of dapagliflozin in a sepsis model reduced oxidative stress (MDA), increased antioxidant levels (GSH), and reduced inflammation (MPO) in the kidney $(p<0.05)$. Dapagliflozin also decreased oxidative stress (MDA) in lung tissue and decreased inflammation (MPO) in lung and liver tissue $(p<0.05)$. Caspase 8 and 9 levels in kidney, lung, and liver tissue were increased $(p<0.05)$ in the dapagliflozin group compared with the sepsis group. According to the histopathological results, sepsis was moderately improved in renal tissue and slightly attenuated in lung and liver tissue with the administration of dapagliflozin.

CONCLUSION: Dapagliflozin had a preventive effect on sepsis-induced kidney damage, but the protective effect was mild in lung and liver tissue in the present study.

Keywords: Apoptosis; dapagliflozin; inflammation; oxidative stress; sepsis.

\section{INTRODUCTION}

Sepsis is defined as serious clinical syndrome which occurs as a consequence of an impaired inflammation response against infection characterized by an abnormal physiological, biological, and biochemical process. ${ }^{[]}$According to a retrospective analysis of international databases, the global incidence rate between 1995 and 2015 was 437 out of 100,000 for sepsis and 270 out of 100,000 for severe sepsis. ${ }^{[2]}$ During the management of sepsis, organ failure must be carefully evaluated because it is well established that damage to the pulmonary system, coagulation mechanism, central nervous system, gastrointestinal system, and renal failure are common problems that can increase mortality. ${ }^{[3]}$ Acute renal damage associated with sepsis and the deleterious effects of organic waste, such as uremic toxins, cause oxidative stress, inflammation, and insulin resistance, and these consequences also affect morbidity and mortality in sepsis. ${ }^{[4]}$ Cecal ligation and puncture (CLP) is a well-designed, easy, and inexpensive polymicrobial septic shock model in experimental animals that also conforms to the human sepsis model. ${ }^{[5-7]}$

Cite this article as: Kıngır ZB, Özdemir Kumral ZN, Çam ME, Çilingir ÖT, Şekerler T, Ercan F, et al. Effects of dapagliflozin in experimental sepsis model in rats. Ulus Travma Acil Cerrahi Derg 2019;25:213-221.

Address for correspondence: Betül Okuyan, Ph.D.

Marmara Üniversitesi Eczacılık Fakültesi, Klinik Eczacılık Anabilim Dalı, İstanbul, Turkey.

Tel: +90 216 - 4140545 E-mail: betulokuyan@yahoo.com 
In many studies, sodium-glucose co-transporter 2 (SGLT2) inhibitors, such as dapagliflozin, have been observed to have antioxidant effects by increasing antioxidant enzymes and reducing oxidative stress markers. Furthermore SGLT2 inhibitors have been reported to reduce inflammatory markers, suppress apoptosis in the cell and have a potential effect on cell healing. ${ }^{[8-12]}$

A literature review revealed that dapagliflozin, a new antidiabetic agent, has not been investigated for its effects on oxidative stress, inflammation, and apoptosis in an experimental sepsis model. Therefore, the objective of this study was to investigate the antioxidant, anti-inflammatory, and antiapoptotic effects of dapagliflozin in rats in a cecal binding and puncture sepsis model.

\section{MATERIALS AND METHODS}

\section{Experimental Animals}

Sprague-Dawley rats (250-350 g) of both sexes supplied by the Experimental Animal Implementation and Research Center of Marmara University were housed in relative humidity $(65-70 \%)$ and a temperature-controlled room $\left(22 \pm 2^{\circ} \mathrm{C}\right)$ with standardized light/dark (12-hour) cycles. The rats were fed with standard rat pellets and had free access to water. This study protocol was approved by Marmara University Animal Experiments Local Ethical Committee (Ethical approval number and date: I15.2016.mar; 12.12.2016).

\section{Experimental Design}

The experimental sepsis model was developed using a CLP procedure. It has been established that the cecum contains a high concentration of Gram-positive and Gram-negative bacteria. This polymicrobial content spreads to the peritoneum in the CLP model and causes sepsis. The rats were randomly divided into a sham or a CLP group, each of which included subjects of both sexes. Anesthesia was provided with a combination of ketamine $100 \mathrm{mg} / \mathrm{kg}$ and xylazine $10 \mathrm{mg} / \mathrm{kg}$. After the midline laparotomy, the cecum was gently pulled out and ligated above the ileocecal valve to maintain bowel passage, 3 perforations were made on the antimesenteric side with a $2 \mathrm{I}$-gauge needle, and feces expression was allowed. The sham-operated control group $(n=16)$ underwent a laparotomy without ligature or punctures and the abdomen was closed appropriately. Data obtained from previous studies indicate that CLP-induced sepsis mortality occurs in the first 3 days. ${ }^{[13]}$ The rats were decapitated 24 hours after the operation. ${ }^{[5,6]}$ The survival rate of the experimental animals was recorded throughout the process. ${ }^{[14-16]}$

Four days before the CLP surgery, saline $(n=8)$ or dapagliflozin $(\mathrm{n}=8 ; 10 \mathrm{mg} / \mathrm{kg}, 10 \mathrm{~mL} / \mathrm{kg}$; Forxiga, AstraZeneca, Cambridge, UK) was administered to the subjects in the sham and dapagliflozin groups. Orogastric gavage was performed in the dapagliflozin-treated CLP group and the sham-operated rats were injected with saline. ${ }^{[9,14,15,17]}$ On day 5 , sepsis was induced using the CLP model and 24 hours later the rats were sacrificed. There were 4 female rats (250-300 g) and 4 male rats $(300-350 \mathrm{~g})$ in each group. Serum and tissue (kidney, lung, liver) samples were obtained and preserved $\left(-80^{\circ} \mathrm{C}\right.$ or $10 \%$ buffered formalin) in order to be used for further biochemical and histological analysis (Fig. I).

\section{Biochemical Analyses}

\section{Measurement of Serum Blood Urea Nitrogen, Creatinine, and Glucose}

The serum blood urea nitrogen (BUN), creatinine, and glucose levels were determined using an auto analyzer according to the manufacturer's instructions (Cobas Integra 400 plus; Roche Diagnostics GmbH, Risch-Rotkreuz, Switzerland).

\section{Measurement of Malondialdehyde and Glutathione}

The level of malondialdehyde (MDA), a byproduct of lipid peroxidation, was measured based on thiobarbituric acid reactive substance formation in kidney, lung, and liver tissues. ${ }^{[18]}$ Tissue samples were homogenized in $10 \%$ trichloroacetic acid solution using 10 -fold dilutions. The homogenized tissue samples were then centrifuged at $2000 \mathrm{~g}$ for 15 minutes at $4^{\circ} \mathrm{C}$; the supernatant was removed and re-centrifuged at $41,400 \mathrm{~g}$ for 8 minutes. The upper organic liquid layer was separated and was measured with a spectrophotometer (Epoch; BioTek Instruments, Inc., Winooski, VT, USA) at $532 \mathrm{~nm}$. Thiobarbituric acid reactive substance formation was measured ${ }^{[19]}$ and the lipid peroxidation measurement was provided in terms of MDA equivalents using an extinction coefficient of $1.56 \times 105 \mathrm{M}^{-1} \mathrm{~cm}^{-1}$ and expressed as nmoL MDA/g tissue.

GSH levels were measured in kidney, lung, and liver tissues according to the method developed by Beutler ${ }^{[20]}$ using a modification of the Ellman procedure. The experimental principle is to measure the colored product resulting from the reaction of the sulphydryl groups with 5-5 'dithiobis I-2

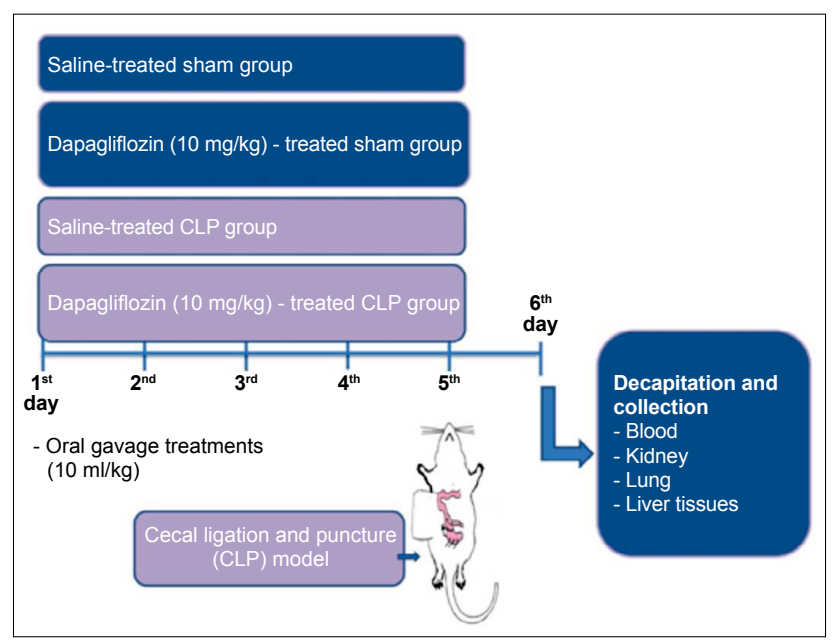

Figure 1. Schematic representation of the experimental design. 
nitrobenzoic acid in the spectrophotometer at $412 \mathrm{~nm}$. The results were expressed as $\mu \mathrm{mol} \mathrm{GSH} / \mathrm{g}$ tissue.

\section{Measurement of Myeloperoxidase Activity}

Myeloperoxidase (MPO) is a member of the peroxidase family. MPO activity in the lysates of kidney, lung, and liver tissues was assessed using a commercial enzyme-linked immunosorbent assay (ELISA) kit (Catalog No: LS-F4305, Lot No: 103692; LifeSpan BioSciences, Inc., Seattle, WA, USA). The results were measured as $\mathrm{U} / \mathrm{g}$ tissue.

\section{Measurement of Interleukin 1 Beta and Tumor Necrosis Factor-Alpha}

Interleukin I beta (IL-I $\beta$ ) and tumor necrosis factor alpha (TNF- $\alpha$ ) levels were measured in all tissues (kidney, lung, liver) with commercial ELISA kits (Catalog No: BMS630, Lot No: 143373023; eBio-science, Inc., San Diego, CA, USA; Catalog No: KRC30II, Lot No: 1818268a; Thermo Fisher Scientific, Inc., Waltham, MA, USA, respec-tively). The results were measured as $\mathrm{ng} / \mathrm{mL}$.

\section{Measurement of Tissue Caspase 8 and Caspase 9}

The kidney, lung, and liver lysates were analyzed to determine caspase 8 and 9 levels with a commercial kit (Catalog No: APTI7I, Lot No: 2829013; Cat. No: APTI73, Lot No: 284I705, respectively; MilliporeSigma, Burlington, MA, USA). The p-nitroaniline absorbance in non-apoptotic specimens and apoptotic specimens was compared and the caspase 8 and 9 activity was calculated as fold increase.

\section{Histological Evaluation}

The samples obtained from kidney, liver, and lung tissues were fixed in 10\% neutral buffered formalin for 48 hours and then examined with routine histological processing. Approximately $4 \mu \mathrm{m}$-thick paraffin sections were stained with hematoxylin and eosin. Periodic acid-Schiff staining was applied to assess the basal membrane and proximal tubules of kidney samples. The sections were examined and photographed using a light microscope (BX5I; Olympus Corp., Tokyo, Japan) attached to a digital camera (DP72; Olympus Corp., Tokyo, Japan). Histologists evaluated the glomerular structure and Bowman's capsule, proximal and distal tubules, interstitial bleeding, and vascular congestion in kidney tissue; damaged hepatocytes with vacuoles and pyknotic nuclei, sinusoidal congestion, and increase of activated Kupffer cells in liver tissue; and alveolar morphology, interstitial bleeding, and vascular congestion in lung tissue.

\section{Statistical Analysis}

Statistical analysis was performed using GraphPad Prism 5.0 (GraphPad Software, Inc. La Jolla, CA, USA). All data are expressed as mean \pm SEM. Relationships within groups were measured using one-way analysis of variance followed by Tukey's post hoc test. $P<0.05$ was considered statistically significant. The odds ratio (OR) was calculated based on a chisquare test for survival rate.

\section{RESULTS}

\section{Survival Rate}

The 24 -hour survival rate was $75 \%$ (6/8 rats) in the salinetreated CLP group, whereas the survival rate was $100 \%$ for the other groups. There was no statistically significant difference in survival between the dapagliflozin-treated CLP group and the saline-treated CLP group (OR: $0.75,95 \%$ confidence interval $[\mathrm{Cl}]$ : 0.50-I. I2; $\mathrm{p}>0.05$ ).

\section{Blood Urea Nitrogen, Creatinine and Glucose Levels}

The CLP surgery groups developed kidney dysfunction and had higher plasma BUN $(p<0.01)$ and creatinine $(p<0.01-$ $0.00 \mathrm{I}$ ) levels in comparison with the saline-treated sham group (Fig. 2).

The glucose level was significantly higher in the dapagliflozintreated sham group compared with the saline-treated sham group $(p<0.05)$. A significant decrease was observed in the saline-treated CLP group when it was compared with the saline-treated sham group $(p<0.0 \mathrm{I})$ (Fig. $2 c)$. (a)

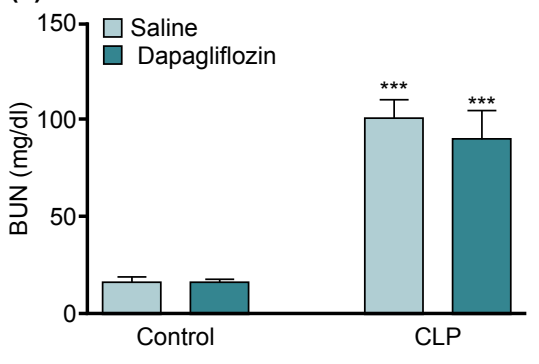

(b)

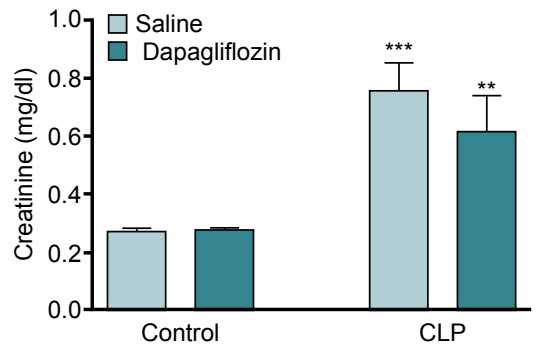

(c)

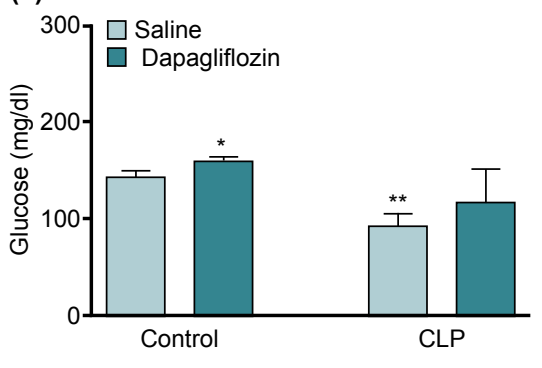

Figure 2. The level of blood urea nitrogen (BUN) and creatinine was increased, and the blood glucose level was decreased in the cecal ligation and puncture (CLP) groups, but dapagliflozin use did not demonstrate a change in the level of these parameters. (a) Serum BUN level after dapagliflozin treatment. (b) Serum creatinine level after dapagliflozin treatment. (c) Body glucose level after dapagliflozin treatment. The data are presented as the mean \pm SEM. One-way analysis of variance and post hoc Tukey-Kramer multiple comparison tests were used. ${ }^{*} p<0.05,{ }^{* *} p<0.01,{ }^{* * *} p<0.001$ vs saline-treated sham group. Each group consisted of $6-8$ samples. 


\section{Malondialdehyde and Glutathione Levels}

The MDA level in all tissues was significantly elevated in the saline-treated CLP group when compared with the salinetreated sham group ( $p<0.05-0.01$; Fig. 3 ). The MDA level in the dapagliflozin-treated CLP group was significantly lower in all tissues than that of the saline-treated CLP group $(p<0.05-$ 0.0I; Fig. 3). Interestingly, the MDA level in the dapagliflozintreated sham group was significantly higher in kidney tissue than that of the saline-treated sham group $(p<0.05)$ (Fig. 3a).

The GSH level was significantly lower in the kidney and hepatic tissue of the saline-treated CLP group when compared with the saline-treated sham group $(p<0.050-00$ I; Fig. $3 \mathrm{~b}$ and $f)$, while an increase in GSH in kidney tissue was observed with administration of dapagliflozin $(p<0.00$ I, Fig. 3).

Myeloperoxidase, Tumor Necrosis Factor Alpha, and Interleukin 1 Beta Levels

MPO activity was found to be significantly high in all of the tissue samples of the saline-treated CLP group when compared with the saline-treated sham group ( $p<0.01-0.001$; Fig. 4). CLP-induced elevation in MPO activity were only significantly decreased in renal tissue in the dapagliflozin-treatment group $(p<0.05$; Fig. 4).

TNF- $\alpha$ and IL-I $\beta$ levels demonstrated a statistically significant increase in the saline-treated CLP group when compared with the saline-treated sham group in lung and liver tissues $(p<0.05-0.001)$. Administration of dapagliflozin significantly diminished these alterations in the saline-treated CLP group ( $p<0.0$ I-0.00I; Fig. 4).

\section{Caspase 8 and 9}

In the saline-treated CLP group, caspase- 8 and 9 activity in kidney, lung, and liver tissues was significantly greater when compared with the saline-treated sham group $(\mathrm{p}<0.0 \mathrm{I}-$ 0.00I; Fig. 5). Dapagliflozin administration did not alleviate CLP-induced apoptosis and there was a significant increase $(p<0.00 I)$ in caspase-8 activity in kidney tissue samples when compared with the saline-treated CLP group.

\section{Histological Evaluation}

Regular morphology of the interstitial space, Bowman's space and glomeruli, proximal and distal tubules were seen in kidney tissues obtained from the saline-treated sham and dapagliflozin-treated sham groups (Fig. 6a, b). In the saline-treated CLP group, interstitial bleeding, glomerular congestion, significant dilation of Bowman's space, and tubular degeneration were observed (Fig. 6c). Regression in the dilation of Bowman's space, tubular degeneration, moderate glomerular congestion, mild interstitial bleeding, and vascular congestion were observed in the dapagliflozin-treated CLP group (Fig. 6d).

Regular parenchyma morphology was also seen in liver tissue collected from the saline and dapagliflozin treated sham groups (Fig. 7a, b). In the saline-treated CLP group, significant sinusoidal congestion, degenerated hepatocytes, and an increased number of activated Kupffer cells were observed

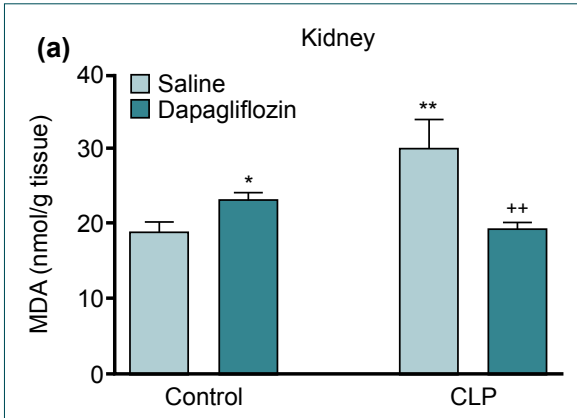

(b)

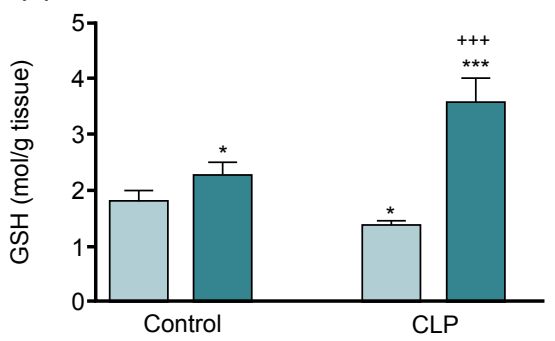

(c)

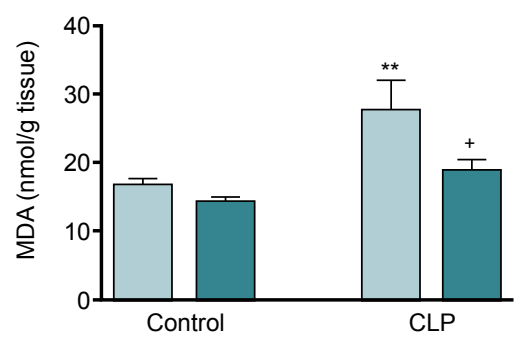

(d)

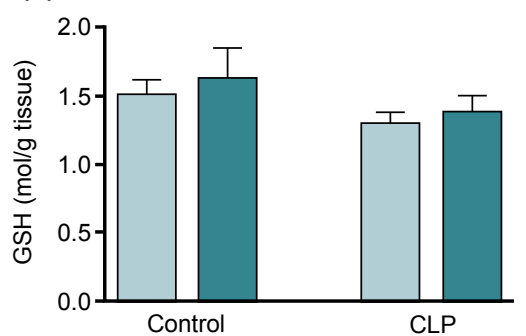

(e)

Liver

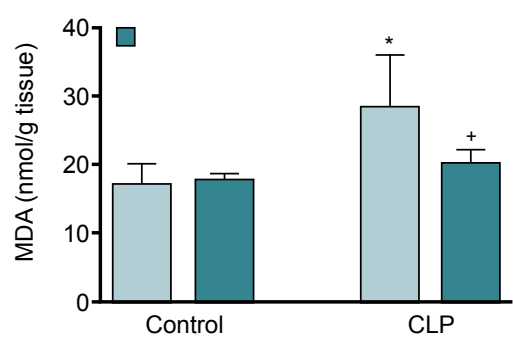

(f)

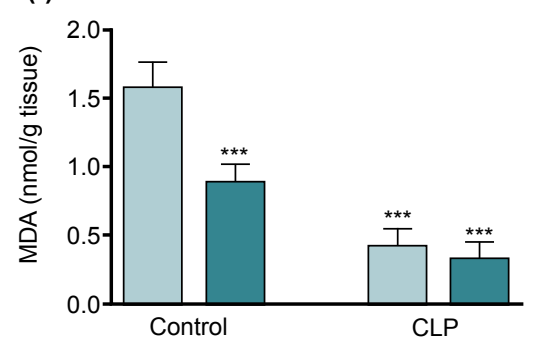

Figure 3. Dapagliflozin reduced the level of malondialdehyde (MDA) in kidney, lung and liver tissue, and increased the level of glutathione (GSH) in kidney tissue. (a) Kidney MDA level after dapagliflozin treatment. (b) Kidney GSH level after dapagliflozin treatment. (c) Lung MDA level after dapagliflozin treatment. (d) Lung GSH level after dapagliflozin treatment. (e) Liver MDA level after dapagliflozin treatment. (f) Liver GSH level after dapagliflozin treatment. The data are presented as the mean \pm SEM. One-way analysis of variance and post hoc Tukey-Kramer multiple comparison tests were used. ${ }^{*} p<0.05$, ${ }^{* *} p<0.01$, ${ }^{* \star *} p<0.001$ vs saline-treated sham group. Each group consisted of 6-8 samples. 


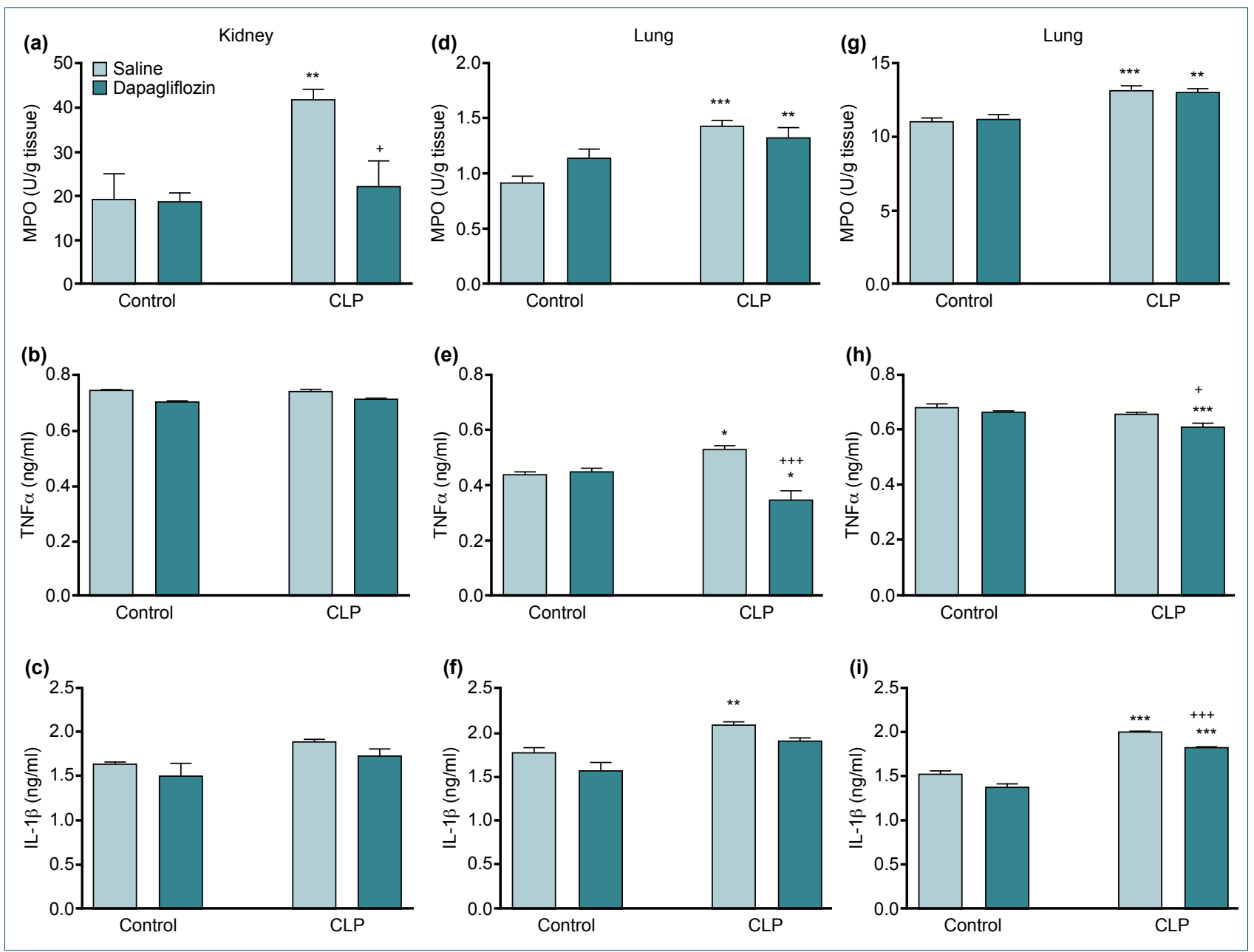

Figure 4. Dapagliflozin reduced the level of myeloperoxidase (MPO) only in kidney tissue, and decreased the level of tumor necrosis factor alpha (TNF- $\alpha$ ) in lung and liver tissue and the level of interleukin 1beta (IL-1 $\beta$ ) in liver tissue. (a) Kidney MPO level after dapagliflozin treatment. (b) Kidney TNF- $\alpha$ level after dapagliflozin treatment. (c) Kidney IL-1 $\beta$ level after dapagliflozin treatment. (d) Lung MPO level after dapagliflozin treatment. (e) Lung TNF- $\alpha$ level after dapagliflozin treatment. (f) Lung IL-1 $\beta$ level after dapagliflozin treatment. (g) Liver MPO level after dapagliflozin treatment. (h) Liver TNF- $\alpha$ level after dapagliflozin treatment. (i) Liver IL-1 $\beta$ level after dapagliflozin treatment. The data are presented as the mean \pm SEM. One-way analysis of variance and post hoc Tukey-Kramer multiple comparison tests were used. ${ }^{*} p<0.05,{ }^{* *} p<0.01,{ }^{* * *} p<0.001$ vs saline-treated sham group. Each group consisted of $6-8$ samples.

(Fig. 7c). Sinusoidal congestion, and degenerated hepatocytes and activated Kupffer cells were reduced in the dapagliflozintreated CLP group (Fig. 7d).

Regular parenchyma morphology was viewed in lung tissue obtained from the saline-treated sham and dapagliflozin-treated sham groups (Fig. 8a, b). Severe interstitial bleed-ing and vascular congestion, cellular debris in the alveolar lu-men, and degenerated alveolar structures were observed in the salinetreated CLP group (Fig. 8c). Moderate interstitial bleeding and vascular congestion, partial degeneration of alveolar structures, cellular debris in the lumen of a number of alveoli, and in some regions, alveoli with regular morphology were seen in the dapagliflozin-treated CLP group (Fig. 8d).

\section{DISCUSSION}

Dapagliflozin reduced oxidative stress (MDA) and inflamma- tion (MPO), but conversely, increased the level of antioxidants (GSH) in the kidney. Recovery of histological features of renal injury was demonstrated. In addition, dapagliflozin treatment decreased oxidative stress (MDA) and inflammation (TNF- $\alpha$ ) in lung tissue. A slight recovery in the histological features of lung injury was noted. Additionally, dapagliflozin treatment lowered inflammation (TNF- $\alpha$, IL-I $\beta$ ), but there was only a limited decrease in the level of oxidative stress in the liver. $A$ slight recovery in the histological features of liver injury was observed.

Immune system function declines with diabetes mellitus. This altered immune response can lead to the progression toward sepsis through the growth of microorganisms. In experimental animal models and diabetic human studies, deficiencies in immunoreactivity have been shown to increase susceptibility to sepsis and other infections. In patients with Type I diabetes, 


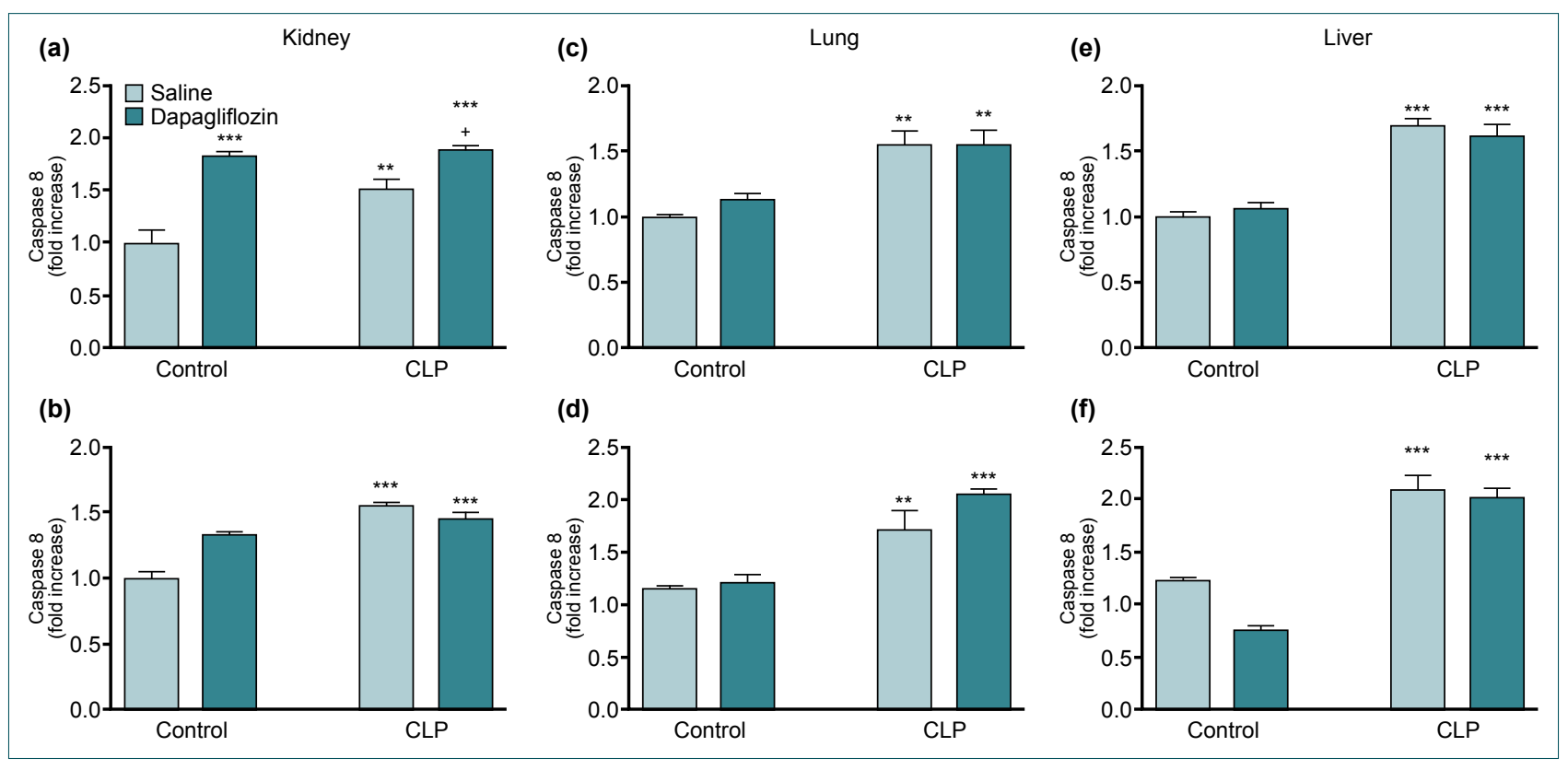

Figure 5. Dapagliflozin increased the level of caspase 8 only in kidney tissue. No changes were observed in the level of caspase 9. (a) Kidney caspase 8 level after dapagliflozin treatment. (b) Kidney caspase 9 level after dapagliflozin treatment. (c) Lung caspase 8 level after dapagliflozin treatment. (d) Lung caspase 9 level after dapagliflozin treatment. (e) Liver caspase 8 level after dapagliflozin treatment. (f) Liver caspase 9 level after dapagliflozin treatment. The data are presented as the mean \pm SEM. One-way analysis of variance and post hoc Tukey-Kramer multiple comparison tests were used. ${ }^{*} p<0.05$, ${ }^{* *} p<0.01$, ${ }^{* * *} p<0.001$ vs saline-treated sham group. Each group consisted of 6-8 samples.
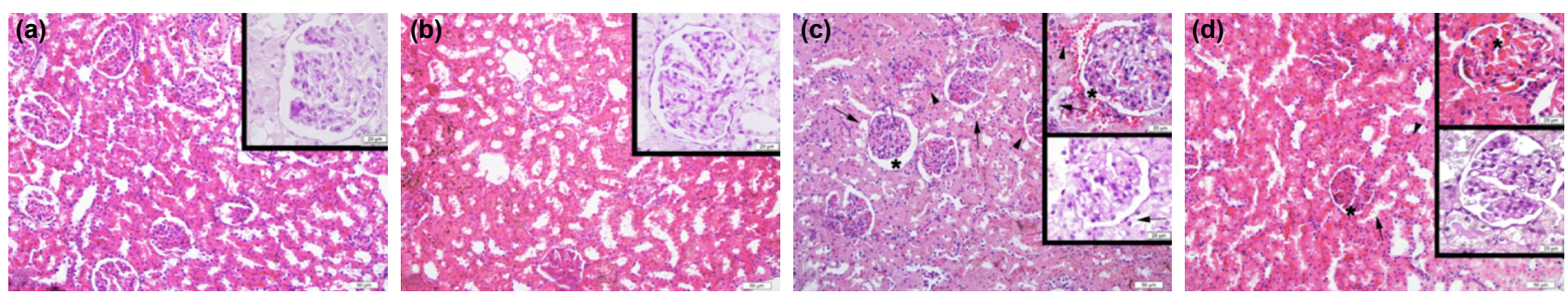

Figure 6. Representative photomicrographs of kidney tissue in the experimental groups. Regular kidney morphology in saline-treated sham control (a) and dapagliflozin-treated sham control (b) groups. Interstitial bleeding (arrowhead) and glomerular congestion, dilation of Bowman's space $\left({ }^{*}\right)$, degenerated tubules (arrow) seen in saline-treated cecal ligation and puncture (CLP) group (c) and Bowman's capsule with regular morphology $\left(^{*}\right)$, mild glomerular congestion $\left({ }^{*}\right.$, upper inset), vascular congestion (arrowhead), and a few damaged tubules (arrow) in the dapagliflozin-treated CLP group (d). H\&E staining, A and B insets, C and D below insets: PAS staining, scale bars: $50 \mu \mathrm{m}(\mathrm{x} 20)$, inset: $20 \mu \mathrm{m}(\mathrm{x} 40)$.
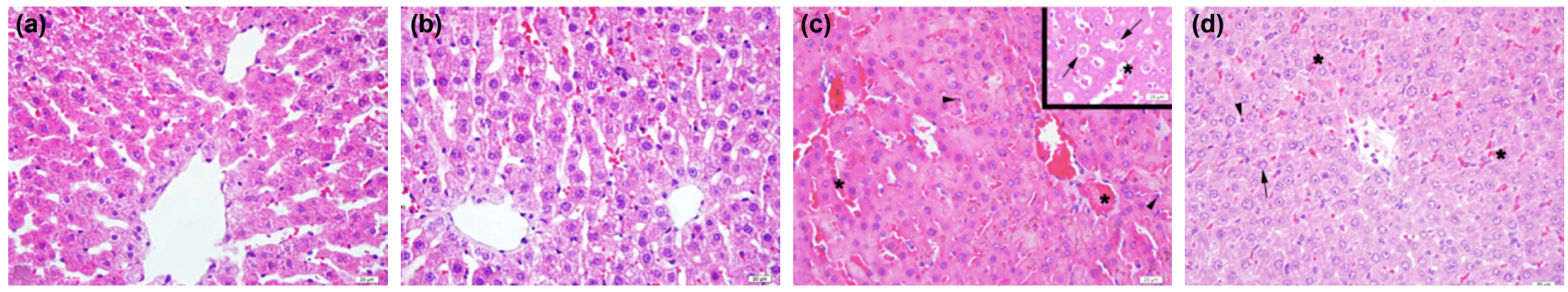

Figure 7. Representative photomicrographs of liver tissue in the experimental groups. Regular liver parenchyma in saline-treated sham control (a) and dapagliflozin-treated sham control (b) groups with severe sinusoidal dilation and congestion (*), numerous damaged hepatocytes (arrow) and activated Kupffer cells (arrowhead), and in the saline-treated cecal ligation and puncture (CLP) group (c), mild sinusoidal congestion ( ${ }^{*}$ ), a few damaged hepatocytes (arrow), and activated Kupffer cells (arrowhead) in the dapagliflozin-treated CLP group (d). H\&E staining, scale bar: $20 \mu \mathrm{m}(\mathrm{x} 40)$.

neutrophil function (chemotaxis, phagocytosis, and cell death), reactive oxygen species production, bacteremia, and sepsis may occur as a result of the impairment in bacterial control at the infection site. The prognosis of patients with sepsis is more pronounced in patients with type 2 diabetes compared with type I diabetes. The mortality rate is significantly high in 

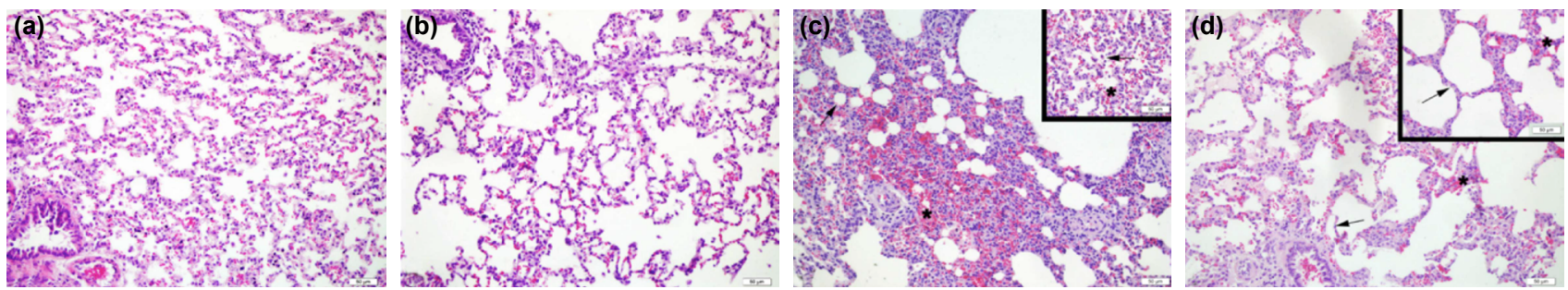

Figure 8. Representative photomicrographs of lung tissue in the experimental groups. Lung parenchyma with regular morphology in the saline-treated sham (a) and dapagliflozin-treated sham (b) groups and severe interstitial bleeding $\left(^{*}\right)$ and vascular congestion, degeneration in alveolar structure (arrow) in the saline-treated cecal ligation and puncture (CLP) group (c) with mild interstitial bleeding $\left({ }^{*}\right)$ and vascular congestion, partly degeneration of alveolar structure (arrow), and regular alveolar morphology (arrow, inset) in the dapagliflozintreated CLP group in some places (d). H\&E staining, scale bars: $50 \mu \mathrm{m}(\mathrm{x} 20)$.

sepsis patients and sepsis can be a common consequence in diabetic patients. Therefore, new treatments are needed. ${ }^{[21]}$ Dapagliflozin, a new drug used in the treatment of diabetes, is an inhibitor of SGLT2. ${ }^{[9]}$ A review of the literature did not reveal any studies of dapagliflozin and sepsis as yet. However, consistent with the results of the present study, it has been reported that dapagliflozin $(10 \mathrm{mg} / \mathrm{kg} /$ day) decreased BUN and creatinin levels in a renal ischemic reperfusion model in rats and had a protective effect on renal tubular cells. ${ }^{[9]}$ In addition, it has been shown that dapagliflozin reduced apoptotic cell death by inducing hypoxia inducible factor I in ischemic renal tissue and ischemic tubular cell cultures and decreasing $\mathrm{Bax} / \mathrm{BcL} 2$ ratio and terminal dUTP nick-end labeling-positive cells. ${ }^{[9]}$

Depending on the characteristics of a critical illness (sepsis, burns, etc.), acute hyperglycemia and insulin resistance can develop even if there is no history of diabetes mellitus in the patient. This condition has been assessed as a stress response. The development of this response may involve the release of inflammatory cytokines such as TNF- $\alpha$ and IL-6; an increase in stress hormones, such as cortisol; and the use of drugs such as corticosteroids. In the case of sepsis or septic shock, hyperglycemia occurs at an early stage and hypoglycemia has a late stage development. ${ }^{[22,23]}$ In our study, the decrease in blood glucose levels in the sepsis group when compared with the control suggests late-stage sepsis. In a study of mice using a sepsis model (CLP), it was demonstrated that blood glucose levels decreased in the sepsis group and that the glucose levels increased in the group given pioglitazone, which is also an anti-diabetic agent. ${ }^{[24]}$ In our study, there was a decrease in blood glucose levels in the CLP group, consistent with other research available in the literature. ${ }^{[23-27]}$ In the present study, although glucose levels were significantly increased in the dapagliflozin-treated sham group, there was no significant change in the glucose levels of the dapagliflozin-treated CLP group. Therefore, the positive findings of the current study do not suggest that dapagliflozin makes a strong contribution to glucose control.

In CLP studies performed on rats, serum TNF- $\alpha$, IL-6, BUN, and creatinine levels were higher in the sepsis group compared with the control group. Increases in MDA and MPO values, a decrease in GSH values, and an increase in apoptosis were observed in the kidney, and histological examination showed renal tissue damage. ${ }^{[28-34]}$ Similar findings were obtained in the sepsis model applied in our study. It was determined that there was no significant difference in the serum creatinine value between the groups, but a significant increase was noted in the CLP group after 72 hours. In addition, oxidative stress parameters and apoptotic (caspase 3 ) values were greater in the CLP group compared with the controls and more tissue damage was determined in the kidney and lung tissue in the histological examination. ${ }^{[35]}$ Serum BUN and creatinine values in our study were consistent with the findings of sepsis (CLP method) in the literature. ${ }^{[8,35]}$ In another study, TNF- $\alpha$, IL-I $\beta$, IL-6, MDA, and MPO levels of lung tissue were greater in the sepsis group compared with the control group. GSH levels were lower. ${ }^{[28,36-40]}$ In the histopathological evaluation, severe tissue damage was reported. ${ }^{[38]}$ These results are also consistent with the findings we obtained in our sepsis model. It has also been reported that there were increases in the levels of caspase 3 and $B a x / B c L ~ 2$ in the lungs. ${ }^{[40]}$

The MDA level in liver tissue was elevated, whereas the GSH level decreased in the sepsis group compared with the controls. ${ }^{[31,39]}$ These results are consistent with our sepsis model. In another study, rats were evaluated 24 hours after CLP, and when the sepsis group was compared with the control group, the MDA level was significantly higher in the liver tissue, but there was no increase in the kidney or lung tissues. MPO values increased in the lung; however, there was no significant difference in the liver or kidney tissues. In the same study, plasma cytokines (TNF- $\alpha, I L-I \beta$, etc.), BUN, and creatinine levels were greater in the CLP group, and there was no significant decline in glucose levels. ${ }^{[25]}$ Other research indicated that there was an increase in kidney MPO values as well as MDA values in kidney and liver tissue, but there was no significant different in liver MPO level. ${ }^{[41]}$

The effect of long-term use of dapagliflozin on glucose homeostasis and diabetic nephropathy has previously been investigated. Dapagliflozin has improved hyperglycemia and albuminuria, depending on the dose $(0.1-1.0 \mathrm{mg} / \mathrm{kg})$, and reduced macrophage infiltration, gene expression of inflammatory cytokines, and oxidative stress in diabetic mice. There was 
no significant difference in BUN or serum creatinine levels. ${ }^{[8]}$ These results are consistent with those of our study. Other researchers found that dapagliflozin reduced oxidative stress and apoptosis induced by high glucose in type I diabetic mice, alleviated diabetic nephropathy, and reduced macrophage infiltration. ${ }^{[42]}$ In another study, the effect of SGLT inhibition on polycystic kidney dysfunction was investigated in rats. Dapagliflozin $(10 \mathrm{mg} / \mathrm{kg}$ ) was found to unexpectedly cause an increase in cyst volume with albuminuria, hyperfiltration, and polycystic kidney failure in rats. ${ }^{[43]}$

Additional studies should be conducted to develop new alternatives for prophylactic treatment of sepsis and to investigate the different effects of this new medicine, dapagliflozin. The results of our study suggest that diabetic patients using dapagliflozin may also benefit from the effect on oxidative stress. As a result, the findings of this study highlighted a possible protective effect of dapagliflozin in renal damage. Dapagliflozin also slightly alleviated lung and liver injury.

\section{Acknowledgement}

This work was supported by Marmara University Scientific Research Projects Committee (SAG-C-YLP-090217-0040), İstanbul, Turkey.

\section{Conflict of interest: None declared.}

\section{REFERENCES}

1. Vincent JL, Opal SM, Marshall JC, Tracey KJ. Sepsis definitions: time for change. Lancet 2013;381:774-5.

2. Fleischmann C, Scherag A, Adhikari NK, Hartog CS, Tsaganos T, Schlattmann P, et al. Assessment of Global Incidence and Mortality of Hospital-treated Sepsis. Current Estimates and Limitations. Am J Respir Crit Care Med 2016;193:259-72.

3. Sungur M. Sepsiste Organ Destek Tedavileri. Yoğun Bakım Dergisi 2005;5:112-21

4. Bilgili B, Haliloğlu M, Cinel İ. Sepsis and Acute Kidney Injury. Turk J Anaesthesiol Reanim 2014;42:294-301.

5. Doi K, Leelahavanichkul A, Yuen PS, Star RA. Animal models of sepsis and sepsis-induced kidney injury. J Clin Invest 2009;119:2868-78.

6. Yilmaz Savcun G, Ozkan E, Dulundu E, Topaloğlu U, Sehirli AO, Tok $\mathrm{OE}$, et al. Antioxidant and anti-inflammatory effects of curcumin against hepatorenal oxidative injury in an experimental sepsis model in rats. Ulus Travma Acil Cerrahi Derg 2013;19:507-15.

7. Rittirsch D, Huber-Lang MS, Flierl MA, Ward PA. Immunodesign of experimental sepsis by cecal ligation and puncture. Nat Protoc 2009;4:31-6.

8. Zhang Y, Thai K, Kepecs DM, Gilbert RE. Sodium-Glucose Linked Cotransporter-2 Inhibition Does Not Attenuate Disease Progression in the Rat Remnant Kidney Model of Chronic Kidney Disease. PLoS One 2016;11:e0144640.

9. Chang YK, Choi H, Jeong JY, Na KR, Lee KW, Lim BJ, et al. Dapagliflozin, SGLT2 Inhibitor, Attenuates Renal Ischemia-Reperfusion Injury. PLoS One 2016;11:e0158810.

10. Terami N, Ogawa D, Tachibana H, Hatanaka T, Wada J, Nakatsuka A, et al. Long-term treatment with the sodium glucose cotransporter 2inhibitor, dapagliflozin, ameliorates glucose homeostasis and diabeticnephropathy in db/db mice. PLoS One 2014;9:e100777.
11. Thomson SC, Rieg T, Miracle C, Mansoury H, Whaley J, Vallon V, et al. Acute and chronic effects of SGLT2 blockade on glomerular and tubular function in the early diabetic rat. Am J Physiol Regul Integr Comp Physiol 2012;302:R75-83.

12. Tahara A, Kurosaki E, Yokono M, Yamajuku D, Kihara R, Hayashizaki Y, et al. Effects of SGLT2 selective inhibitor ipragliflozin on hyperglycemia, hyperlipidemia, hepatic steatosis, oxidative stress, inflammation, and obesity in type 2 diabetic mice. Eur J Pharmacol 2013;715:246-55.

13. Craciun FL, Schuller ER, Remick DG. Early enhanced local neutrophil recruitment in peritonitis-induced sepsis improves bacterial clearance and survival. J Immunol 2010;185:6930-8.

14. Shafaroodi H, Hassanipour M, Mousavi Z, Rahimi N, Dehpour AR. The Effects of Sub-Chronic Treatment with Pioglitazone on the Septic Mice Mortality in the Model of Cecal Ligation and Puncture: Involvement of Nitric Oxide Pathway. Acta Med Iran 2015;53:608-16.

15. Tsujimura Y, Matsutani T, Matsuda A, Kutsukake M, Uchida E, Sasajima $\mathrm{K}$, et al. Effects of pioglitazone on survival and omental adipocyte function in mice with sepsis induced by cecal ligation and puncture. J Surg Res 2011;171:e215-21.

16. Gao M, Jiang Y, Xiao X, Peng Y, Xiao X, Yang M. Protective effect of pioglitazone on sepsis-induced intestinal injury in a rodent model.J Surg Res 2015;195:550-8.

17. Rodriguez D, Kapoor S, Edenhofer I, Segerer S, Riwanto M, Kipar A, et al. Inhibition of Sodium-Glucose Cotransporter 2 with Dapagliflozin in Han: SPRD Rats with Polycystic Kidney Disease. Kidney Blood Press Res 2015;40:638-47.

18. Ohkawa H, Ohishi N, Yagi K. Assay for lipid peroxides in animal tissues by thiobarbituric acid reaction. Anal Biochem 1979;95:351-8.

19. Casini AF, Ferrali M, Pompella A, Maellaro E, Comporti M. Lipid peroxidation and cellular damage in extrahepatic tissues of bromobenzeneintoxicated mice. Am J Pathol 1986;123:520-31.

20. Beutler S. Glutathione in red blood cell metabolism. In: Beutler E, editor. A manual of biochemical methods. 2nd ed. New York: Grune and Stratton; 1975. p. 112-14.

21. Trevelin SC, Carlos D, Beretta M, da Silva JS, Cunha FQ. Diabetes Mellitus and Sepsis: A Challenging Association. Shock 2017;47:276-87.

22. Ürkmez S. Sepsiste Kan Şekeri Kontrolü. İÜ Cerrahpaşa Tip Fakültesi Sürekli Tıp Eğitimi Etkinlikleri: Güncel Bilgiler Işığında Sepsis Sempozyum Dizisi. 2006;51:89-97.

23. Ferreira FBD, Dos Santos C, Bruxel MA, Nunes EA, Spiller F, Rafacho A. Glucose homeostasis in two degrees of sepsis lethality induced by caecum ligation and puncture in mice. Int J Exp Pathol 2017;98:329-40.

24. Kaplan J, Nowell M, Chima R, Zingarelli B. Pioglitazone reduces inflammation through inhibition of NF-KB in polymicrobial sepsis. Innate Immun 2014;20:519-28.

25. Ahmad A, Druzhyna N, Szabo C. Delayed Treatment with Sodium Hydrosulfide Improves Regional Blood Flow and Alleviates Cecal Ligation and Puncture (CLP)-Induced Septic Shock. Shock 2016;46:183-93.

26. Heuer JG, Bailey DL, Sharma GR, Zhang T, Ding C, Ford A, et al. Cecal ligation and puncture with total parenteral nutrition: a clinically relevant model of the metabolic, hormonal, and inflammatory dysfunction associated with critical illness. J Surg Res 2004;121:178-86.

27. Yamashita H, Ishikawa M, Inoue T, Usami M, Usami Y, Kotani J. Interleukin-18 Reduces Blood Glucose and Modulates PlasmaCorticosterone in a Septic Mouse Model. Shock 2017;47:455-462.

28. Cadirci E, Halici Z, Odabasoglu F, Albayrak A, Karakus E, Unal D, et al. Sildenafil treatment attenuates lung and kidney injury due to overproduction of oxidant activity in a rat model of sepsis: a biochemical and histopathological study. Clin Exp Immunol 2011;166:374-84.

29. Wang A, Xiao Z, Zhou L, Zhang J, Li X, He Q. The protective effect of atractylenolide I on systemic inflammation in the mouse model of sepsis created by cecal ligation and puncture. Pharm Biol 2016;54:146-50. 
30. Xu L, Nagata N, Nagashimada M, Zhuge F, Ni Y, Chen G, et al. SGLT2 Inhibition by Empagliflozin Promotes Fat Utilization and Browning and Attenuates Inflammation and Insulin Resistance by Polarizing M2 Macrophages in Diet-induced Obese Mice. EBioMedicine 2017;20:13749.

31. Aydın S, Şahin TT, Bacanlı M, Taner G, Başaran AA, Aydın M, et al. Resveratrol Protects Sepsis-Induced Oxidative DNA Damage in Liver and Kidney of Rats. Balkan Med J 2016;33:594-601.

32. Yu C, Li P, Qi D, Wang L, Qu HL, Zhang YJ, et al. Osthole protects sepsis-induced acute kidney injury via down-regulating NF- $\mathrm{KB}$ signal pathway. Oncotarget 2017;8:4796-813.

33. Başol N, Erbaş O, Çavuşoğlu T, Meral A, Ateş U. Beneficial effects of agomelatine in experimental model of sepsis-related acute kidney injury. Ulus Travma Acil Cerrahi Derg 2016;22:121-6.

34. Zhao WY, Zhang L, Sui MX, Zhu YH, Zeng L. Protective effects of sirtuin 3 in a murine model of sepsis-inducedacute kidney injury. Sci Rep 2016;6:33201.

35. Sung PH, Chang CL, Tsai TH, Chang LT, Leu S, Chen YL, et al. Apoptotic adipose-derived mesenchymal stem cell therapy protectsagainst lung and kidney injury in sepsis syndrome caused by cecalligation puncture in rats. Stem Cell Res Ther 2013;4:155.

36. Chen HH, Chang CL, Lin KC, Sung PH, Chai HT, Zhen YY, et al. Melatonin augments apoptotic adipose-derived mesenchymal stem cell treatment against sepsis-induced acute lung injury. Am J Transl Res 2014;6:439-58.
37. Zolali E, Asgharian P, Hamishehkar H, Kouhsoltani M, Khodaii H, Hamishehkar H. Effects of gamma oryzanol on factors of oxidative stress and sepsis-induced lung injury in experimental animal model. Iran J Basic Med Sci 2015;18:1257-63.

38. Zong Y, Zhang H. Amentoflavone prevents sepsis-associated acute lung injury through Nrf2-GCLc-mediated upregulation of glutathione. Acta Biochim Pol 2017;64:93-8.

39. Aliomrani M, Sepand MR, Mirzaei HR, Kazemi AR, Nekonam S, Sabzevari O. Effects of phloretin on oxidative and inflammatory reaction in ratmodel of cecal ligation and puncture induced sepsis. Daru 2016;24:15.

40. Ge L, Hu Q, Shi M, Yang H, Zhu G. Design and discovery of novel thiazole derivatives as potential MMP inhibitors to protect against acute lung injury in sepsis rats via attenuation of inflammation and apoptotic oxidative stress. Rsc Advances 2017;7:32909-22.

41. Aksoy AN, Toker A, Celık M, Aksoy M, Halıcı Z, Aksoy H. The effect of progesterone on systemic inflammation and oxidative stress in the rat model of sepsis. Indian J Pharmacol 2014;46:622-6.

42. Hatanaka T, Ogawa D, Tachibana H, Eguchi J, Inoue T, Yamada H, et al. Inhibition of SGLT2 alleviates diabetic nephropathy by suppressinghigh glucose-induced oxidative stress in type 1 diabetic mice. Pharmacol Res Perspect 2016;4:e00239.

43. Kapoor S, Rodriguez D, Riwanto M, Edenhofer I, Segerer S, Mitchell $\mathrm{K}$, et al. Effect of Sodium-Glucose Cotransport Inhibition on Polycystic Kidney Disease Progression in PCK Rats. PLoS One 2015;10:e0125603.

\title{
DENEYSEL ÇALIŞMA - ÖZET
}

\section{Dapagliflozin' in sıçanlarda deneysel sepsis modeli üzerine etkileri}

\section{Zehra Betül Kıngır, ${ }^{1}$ Dr. Zarife Nigar Özdemir-Kumral, ${ }^{2}$ Dr. Muhammet Emin Çam, ${ }^{3}$ Dr. Özlem Tuğçe Çilingir, ${ }^{4}$ Turgut Şekerler, ${ }^{5}$ Dr. Feriha Ercan, ${ }^{4}$ Dr. Özlem Bingol-Özakpınar, ${ }^{5}$ Dr. Derya Özsavcı, ${ }^{5}$ Dr. Mesut Sancar, ${ }^{1}$ Dr. Betül Okuyan ${ }^{1}$}

\author{
${ }^{1}$ Marmara Üniversitesi Eczacılık Fakültesi, Klinik Eczacılık Anabilim Dalı, İstanbul \\ ${ }^{2}$ Marmara Üniversitesi Tıp Fakültesi, Fizyoloji Anabilim Dalı, İstanbul \\ ${ }^{3}$ Marmara Üniversitesi Eczacılık Fakültesi, Farmakoloji Anabilim Dalı, İstanbul \\ ${ }^{4}$ Marmara Üniversitesi Tıp Fakültesi, Histoloji ve Embriyoloji Anabilim Dalı, İstanbul \\ ${ }^{5}$ Marmara Üniversitesi Eczacılık Fakültesi, Biyokimya Anabilim Dalı, İstanbul
}

AMAÇ: Bu çalışmada, sıçanlarda dapagiflozinin deneysel sepsis modeli üzerindeki olası koruyucu etkilerinin değerlendirilmesi amaçlandı.

GEREÇ VE YÖNTEM: Sprague-Dawley sıçanlara cerrahi operasyonların 5 gün öncesinde serum fizyolojik (I mL/kg, p.o.) veya dapagliflozin (I0 $\mathrm{mg} / \mathrm{kg}$, p.o.) verilmeye başlandı. Sepsis, anestezi altında, çekal ligasyon ve perforasyon modeli ile oluşturulurken, sham kontrol gruplarına sadece laparotomi yapıldı. Serumda BUN, kreatinin ve glukoz düzeyleri; dokularda (böbrek, karaciğer ve akciğer) ise MDA, GSH, MPO, TNF- $\alpha$, IL-I $\beta$, kaspaz 8 ve kaspaz 9 düzeyleri belirlendi. Bu dokularda histolojik değerlendirme de yapıldı.

BULGULAR: Sepsiste dapagliflozin uygulaması, böbrek dokularında oksidatif stresi (MDA) azalttı, antioksidan düzeyleri (GSH) arttırdı ve enflamasyonu (MPO) azalttı $(p<0.05)$. Sepsiste dapagliflozin uygulaması akciğer dokularında oksidatif stresi (MDA) azalttı, akciğer ve karaciğer dokularında ise enflamasyonu (MPO) azalttı $(p<0.05)$. Ayrıca, böbrek, akciğer ve karaciğer dokularında kaspaz 8 ve 9 düzeylerini arttırdı $(p<0.05)$. Histopatolojik sonuçlara göre, dapagliflozin uygulaması böbrek dokularında orta derece; akciğer ve karaciğer dokularında ise hafif iyileştirdi.

TARTIŞMA: Bu çalışmada, dapagliflozinin deneysel sepsis modelinde böbrek hasarını önleyici etkisinin olduğu gösterilmesine rağmen akciğer ve karaciğer dokuları üzerine hafif koruyucu etkisi olduğu bulunmuştur.

Anahtar sözcükler: Apoptoz; dapagliflozin; enflamasyon; oksidatif stres; sepsis.

Ulus Travma Acil Cerrahi Derg 2019;25(3):213-22। doi: |0.5505/tjtes.2018.82826 